\title{
Marketing Efficiency of Camel Milk under Different Supply Chains in Rajasthan State of India
}

\author{
Gurbir Singh $^{1} *$, Amita Sharma ${ }^{1}$ and Raghvendar Singh ${ }^{2}$ \\ ${ }^{1}$ Institute of Agri-Business Management, S.K. Rajasthan Agricultural University, \\ Bikaner, 334006, India \\ ${ }^{2}$ ICAR-Central Sheep \& Wool Research Institute, Avikanagar (Malpura), \\ District-Tonk Rajasthan (304501), India
}

*Corresponding author

\section{A B S T R A C T}

Keywords

Marketing

efficiency, Supply chains, Rajasthan,

Price spread

Article Info

Accepted:

10 November 2019

Available Online:

10 December 2019
The camel rearing communities in Rajasthan are witnessing the degradation of livelihood which they were doing for decades. Camels that were previously used for the transportation of goods and men are now not a viable option due to the affordability of fossil fuel transportation. The marketing camel milk has been studied by four supply chains, viz., I: Camel rearers $\rightarrow$ Camel milk trader $\rightarrow$ Consumer; II: Camel rearers $\rightarrow$ Collection Centre (Centre bear the cost of collection) $\rightarrow$ Consumer; III: Camel rearers $\rightarrow$ Collection Centre (Rearers bear the cost of collection) $\rightarrow$ Consumer; IV: Camel rearers $\rightarrow$ Consumer. The supply chain IV has been found most efficient because its marketing efficiency was 12 as compared to 0.29 in the supply chain I, 0.50 in supply chain II and 0.42 in supply chain III. There is a need to build market infrastructure with a publicprivate partnership to bring efficiency in the marketing of camel milk.

\section{Introduction}

Camel is a very useful animal in the dry desert region. It can survive in the arid region where water scarcity is very prominent, the fodder is scarcely available and harsh weather conditions span perennially. These properties of camels make them ideal for the desert ecosystem. The population of camels is 26.99 million in the world. In India, the camels are found mainly in Rajasthan (81.4\%), Gujarat (7.6\%), Haryana (4.7\%), Bihar (2.2\%) and Uttar Pradesh (2.0\%) and Other States (2.13\%), as per 19th Livestock Census-2012. The global camel population is spread across 47 countries and about 83 percent of the camel population lives mainly in the Eastern and Northern Africa and rest are present in the 
Indian sub-continent and the Middle East. Somalia, a country in the African continent has the highest population of 7.10 million. India stands tenth in the world with 0.38 million camels (FAOSTAT-2015). There is an increasing trend in the world camel population because of a threefold increase in the African region while there is a decreasing trend in the Asian region which includes India also.

On 29th November 2016, the Food Safety and Standards Authority of India (FSSAI) have approved camel milk for sale purposes. It is good news for the camel rearers and camel milk entrepreneurs. Camel milk has been known for therapeutic potential against many diseases including cancer, insulin-dependent diabetes mellitus (IDDM), infant diarrhea, autism and alcohol-induced liver damage mentioned by (Singh et al., 2017). It contains extraordinarily high levels of the insulin-like molecules. Even, camel milk has been reported to possess medicinal value against various ailments such as dropsy, jaundice, spleen ailments, tuberculosis, asthma, anemia, piles, and food allergies. It is shown that camel milk has a beneficial action on chronic liver patients, in chronic fatigue and as a supplement to mother's milk.

In Indian context, there are many evidences of attempts made to analyse, the importance of camel milk as a medicinal element. The importance of camel milk was framed by different authors in a systematically manner started from Khanna (1991) studied that six lactating camels were provided supplementary ration for production. The calves were allowed to suckle after the milking. The peak milk yield was observed between 1 to 2 months of lactation as $7.6 \mathrm{~kg}$ per day. It declined thereafter and reached $6 \mathrm{~kg}$ per day between 3 to 4 months. After six months of lactation, the yield was $4.9 \mathrm{~kg}$ per day after that the trial was conducted in collaboration with the department of T.B. and chest disease (S.P.
Medical College, Bikaner) to evaluate the therapeutic utility of raw and camel milk as a nutritional supplement in chronic preliminary tuberculosis patients. The treatment groups were provided with almost similar therapy and diet along with raw camel milk one $\mathrm{kg} /$ day for a period of three months, while the control group was supplemented with only cow's milk. The patients in the treatment group showed an increase in appetite as well as in body weight (Mal et al., 2000). Ethnic communities on symptoms of diabetes band. The 'Raika' community living in parts of Rajasthan was found with a low prevalence of diabetes due to the consumption of camel milk and the availability of camel milk among Raikas (Agarwal et al., 2005). The prevalence of diabetes in camel milk consuming 'Raika' rural community of northwest Rajasthan. They made a comparative study of the Raika and non-Raika community in the same region and concluded that the Raika community subject to lower impaired fasting glucose as compared to the non-Raika community. Raika is a community that cares camel and also consumes camel milk containing insulin or insulin-like proteins 52 units/Litre (source: test conducted by ICAR-National Research Centre on Camel, Bikaner NRCC). The high level of insulin in camel's milk and the antibodies, which are much simpler in structure than human milk antibodies, enable it to penetrate deeper into the human tissue and cells, which means that the camel milk has the potential to serve as a major weapon against many human illnesses (Agrawal et al., 2004). The comparative fat digestibility of goat, camel, cow and buffalo milk was analyzed. They found that the amount of free fatty acids released per unit volume of the milk sample decreased in the following order:goat $>$ camel $>$ cow $>$ buffalo. They found that camel milk and goat milk has the highest fat digestibility because of the small size of fat globules. Lipids are the most energy-dense macronutrient. Its over-consumption leads to 
many health alignments and diseases. The preferred diet of milk includes milk lipids. The core of fat globules contains about $98-99 \%$ of triacylglycerol. The fat digestibility varies from species to species. The study investigates important insights that influence milk fat digestion in infants and the activity of lipases during in vivo lipid digestion (Meena et al., 2014).Singh (2004) stated in the workshop organized by LPPS on the camel milk ice cream testing experiment. One variant of ice cream is called "Kulfi" in India. It is made without adding cream and condensing milk that is flavored and frozen. This low calorie treats immediately captured the imagination of national and international media and the local tourism business, and it is now marketed by LPPS at local fairs and to restaurant owners.

To do a reasonable comparison, the price charged from the consumer is kept the same for all marketing channels into consideration along with the assumption that all marketing channels are serving in the same market areas. Therefore, the consumer price for all marketing channels should be the same. The research is focused on how much camel rearer gets for his camel milk produce. He must be getting a different price of his produce from different channels due to differences in working style and approach to the business of each marketing channel.

The present study is different from previous studies in the sense that it focuses on the camel milk marketing as an inevitable factor for any entrepreneurship model. The marketing of a product is done through various marketing channels. From the point of producer i.e. camel rearers, it is important to understand and compare the marketing efficiencies of various marketing channels. The present paper was divided in two sections. After presenting in background the importance of camel milk the paper covered the marketing channels for the supply chain of camel milk across the different parts of the India. Therefore, the present study was focused on the marketing efficiency of different supply chain systems in the case of camel milk in the Rajasthan state.

\section{Materials and Methods}

The study was conducted in the potential camel rearers areas in the districts of Bikaner, Jodhpur, Jaisalmer, Aravali range, Pali, Sirohi, Sadri and Dausa of Rajasthan State to assess the extent awareness about the benefits of camel milk among consumers and estimation of different marketing cost and margin among the supply chains.

\section{Collection of data}

\section{Sources of data}

Both primary and secondary data were collected for the study.

\section{Primary data}

Primary data were collected through means of a structured comprehensive schedule from the camel rearers, consumers and emerging entrepreneurs.

\section{Secondary data}

Secondary data have been collected from the Ministry of Agriculture, Department of Animal Husbandry, Dairying, and Fisheries, a report published thesis work, unpublished thesis works, websites and research articles from journals. The Rajasthan state was selected on the basis of the fact that the maximum number of camels in India is in Rajasthan. The potential camel milk pocket areas were suggested by ICAR-National Research Centre on Camel, Bikaner (NRCC). Then, 200 camel rearers were selected through convenience sampling and the rearers were 
contacted on village level and they were asked about problems faced in camel milk marketing, their socio-economic demography to zero in the key problem areas for framing the entrepreneurship model for camel milk entrepreneurs and entrepreneurship development model for the state. The 200 consumers were also selected through convenience sampling for the study.

\section{Objective 1: To study awareness about benefits of camel milk among consumers}

The objective has aimed to study the percent awareness and unawareness of camel milk health benefits from the group of 200 camel milk consumers. According to collecting data decreasing order of awareness and unawareness percent trend shown in a tabular formation.

\section{Objective 2: To estimate the marketing cost} and marketing margin for camel milk under different supply chains

In order to identify and quantify the marketing cost and marketing margin for camel milk under different supply chains, Acharya's Modified Formula for marketing efficiency was adopted. Based on Acharya's Modified Formula four marketing channels marketing efficiency and price spread in each channel were calculated.

\section{Results and Discussion}

Government of Rajasthan declared camel as the state animal on 30th June 2014. The Dromedary and Bactrian are the two species of the camel. The Dromedary species are found in the western parts of India (Rajasthan, Haryana, Gujarat and Punjab) and Bactrian are native to Central and East Asia. They are classified on the basis of single hump and double hump respectively. The state wise camel population indicates that 0.498 million in Rajasthan, 0.128 million in Gujarat and 0.058 million in Haryana. Camel population in these states constitutes about 93.12 per cent of Indian camel population (19th Livestock Census-2012). The decreasing camel population is a biggest hurdle in the establishment of the revenue model for camel milk marketing. According to the studies conducted by ICAR-National Research Centre on Camel, Bikaner; the main reasons for declining population of Indian camels are phenomenal drop rate of 25.6 per cent in 2003, proliferation of diseases, decline in pasture land and distorted male female ratio. Before declaration of camel as state animal of Rajasthan, camels were traded for meat also. One group of experts says that the trading of camels for meat is the reason for major decline of camel population. The other group of experts says that as there is no demand for camel meat, so no demand for camels and consequently, it subdued the interest in breeding the camel.

The camel milk pricing should be done on the basis of medicinal value not on the basis of fat percentage as done in other cattle milk pricing system. As the fat content is lesser than 2.5 per cent it will not fetch price on the basis of fat percentage. Camel milk is being investigated by ICAR-National Research Centre on Camel, Bikaner for commercial utilization and purpose of this study is to find out the suitable business model for camel milk marketing so that it becomes a sustainable, alternative and decent income for camel rearers.

\section{Profile of camel rearers}

Majority of camel rearers were illiterate (40.5 percent) followed by respondents who can read and write (35.5 percent), respondents who can read-only (15.5 percent), respondents educated up to primary (3.5 percent), respondents studied high school (2.5 percent), 
respondents studied middle education (1.5 percent) and respondents studied graduation (1 percent). The current generation is going for higher education while the past generation was illiterate, and they can read and write only.

The majority of the population was having traditional household necessities followed by modern and luxurious household possessions. The material possessions had been categorized into three categories. The traditional category is based on camel rearer living in remote locations with basic necessities, modern category on the basis of camel rearers owning improved living equipment's like the sewing machine, telephone, LPG and luxurious category on the basis of camel rearers owning a television, laptop, generator, washing machine, refrigerator, any four-wheeler.

\section{Awareness of consumers regarding camel milk}

The majority of the camel milk customers are having specific health problems, particularly autism, but diabetes, liver diseases, skin diseases, and bone problems are also mentioned as motivation for buying camel milk. A few customers believe in camel milk as a general health tonic that raises their immunity status. There are indications that raw, unpasteurized camel milk is especially effective for autism. As a safe delivery system cannot currently be envisaged, marketing pasteurized milk is the best option at the moment. Whilst a large number of customers enquire about the availability of camel milk powder, the efficacy of milk powder is uncertain. The key area for developing sales is in marketing towards diabetics, estimated at around 40.9 million in India and set to rise to 69.9 million. A significant clinical study on the efficacy of camel milk as a natural insulin regulator for both Type 1 and Type II diabetes could have immense value not only for camel milk market development but for public health, and presents an opportunity for prestigious, landmark research. Customers require a premium product that is pure and unadulterated. Fat content is of no concern to them; in fact, a low-fat content is considered more desirable. It must be noted that the fat content of the milk from the same camel fluctuates seasonally from as low as 1 percent to more than 4 percent. In order to supply the kind of premium product that is required by the market, the milk has to be carefully handled from the producer stage all the way to the end customer or retailer.

As shown in Table 1 different factors of awareness level of respondents regarding camel milk, most of the people were aware of the benefits of camel milk. This table represents the awareness level of respondents regarding camel milk in descending order of awareness proportions.

\section{Marketing efficiency of camel milk}

The marketing channels were studied and the best marketing channel was identified. Marketing efficiency of various channels has been calculated by using following formula defined by Acharya and Agarwal (2001).

$\mathrm{ME}=\mathrm{MP} /(\mathrm{MC}+\mathrm{MM})$

Here,

Marketing Efficiency (ME)

Total Marketing Costs (MC)

Marketing Margin (MM)

Prices received by the farmer/manufacturer (MP)

The marketing channel which gives highest value of M.E has been considered as efficient marketing channel. Four types of marketing 
channels were considered as they were prevalent in the sample area:

Marketing Channel I: Camel rearers $\rightarrow$ Camel milk trader $\rightarrow$ Consumer

Marketing Channel II: Camel rearers $\rightarrow$ Collection Centre (Centre bear the cost of collection) $\rightarrow$ Consumer

Marketing Channel III: Camel rearers $\rightarrow$ Collection Centre (Rearers bear the cost of collection) $\rightarrow$ Consumer

Marketing Channel IV: Camel rearers $\rightarrow$ Consumer

In camel milk marketing channel, manufacturer price represent the price received by camel rearer for camel milk. Marketing cost includes all types of costs incurring from camel rearer to consumer. This may include costs related to transportation, pasteurization, handling, chilling, labeling, processing etc. Marketing margin is the profit margin added after total marketing cost incurred. Consumer is charged price which is actually a sum of price received by rearer, marketing cost and marketing margin.

To understand marketing efficiency of each channel, price spread was calculated for each marketing channel (Table 2).

\section{Price spread}

\section{Price spread in marketing channel I}

$($ Camel rearers $\rightarrow$ Camel milk $\quad$ Trader $\rightarrow$ Consumer)

In this channel, the camel milk is produced by camel rearers and camel milk trader collects the milk and sells it to the consumer. The camel milk trader is a person who is collecting the camel milk and distributing it in the nearby areas. As camel milk has very limited resources therefore his approach is very limited in comparison to organized players like cooperatives and companies.

Marketing Efficiency for Marketing Channel I is as follows:

$\mathrm{ME}=\mathrm{MP} /(\mathrm{MC}+\mathrm{MM})=35 /(49.85+70.15)=$ 0.29

The marketing efficiency (ME) for Marketing Channel I is 0.29 .

\section{Price spread in marketing channel II}

(Camel rearers $\rightarrow$ Collection Centre (Centre bear the cost of collection) $\rightarrow$ Consumer)

In this channel, the camel rearer produces camel milk and transport the camel milk to collection centre. The collection center could be part of cooperative which sells to the consumer through retail outlet or doorstep delivery. Generally, cooperative are social enterprise and it gives better prices to the farmer/producer than a private player/camel milk trader.

Therefore, camel rearer gets `60/litre and this price is being offered to the camel rearers by LPPS (A camel milk cooperative operating in Jaiselmer). Following table 3 shows price spread in Marketing Channel II:

Marketing Efficiency for Marketing Channel II is as follows:

$$
\begin{aligned}
& \mathrm{ME}=\mathrm{MP} /(\mathrm{MC}+\mathrm{MM})=60 /(79.75+40.25) \\
& =0.50
\end{aligned}
$$

The marketing efficiency (ME) for Marketing Channel II is 0.50 . 
Table.1 Awareness of consumers regarding camel milk

\begin{tabular}{|c|c|c|c|}
\hline S. No. & Facts about camel milk & $\begin{array}{c}\text { Percent } \\
\text { Aware }\end{array}$ & $\begin{array}{c}\text { Percent } \\
\text { Unaware }\end{array}$ \\
\hline 1 & $\begin{array}{l}\text { Presence of minerals like Iron, Copper, Zinc and } \\
\text { Vitamins B1, B6, B12 and Vitamin C in camel milk }\end{array}$ & 60 & 40 \\
\hline 2 & $\begin{array}{c}\text { Camel milk has also proved its role in the treatment } \\
\text { of autism in children }\end{array}$ & 50 & 50 \\
\hline 3 & $\begin{array}{l}\text { Camel milk helps in the management of } \\
\text { tuberculosis, hepatitis-C, and general skin infections }\end{array}$ & 35 & 65 \\
\hline 4 & Camel milk is good for human consumption & 30 & 70 \\
\hline 5 & $\begin{array}{l}\text { Camel milk is effective as probiotic in the } \\
\text { conditions of diarrhea, allergy and respiratory } \\
\text { diseases }\end{array}$ & 30 & 70 \\
\hline 6 & $\begin{array}{c}\text { Camel milk is helpful in the management of type } 1 \\
\text { diabetes }\end{array}$ & 30 & 70 \\
\hline 7 & $\begin{array}{l}\text { Camel milk is helpful for children having milk } \\
\text { allergy with cow milk }\end{array}$ & 20 & 80 \\
\hline 8 & Approval of Camel milk by FSSAI & 10 & 90 \\
\hline 9 & $\begin{array}{c}\text { Presence of insulin and insulin-like protein (45-128 } \\
\text { unit/l) in camel milk }\end{array}$ & 10 & 90 \\
\hline 10 & Presence of immunoglobulin in camel milk & 10 & 90 \\
\hline
\end{tabular}

Source: Author's own computation based on field data 2018

Table.2 Calculation of marketing efficiency for marketing channel I

\begin{tabular}{|c|c|c|}
\hline Particulars & Value & Percent \\
\hline Selling price of camel milk @ 35/litre (FP) & $\mathbf{3 5}$ & $\mathbf{2 9 . 1 7}$ \\
\hline Purchase price of milk trader & 35 & \\
\hline Transportation cost & 2 & 1.67 \\
\hline Bottles/ bottling charges & 4.35 & 3.63 \\
\hline Ice & 7.50 & 6.25 \\
\hline Miscellaneous expenses & 1.00 & 0.83 \\
\hline Total cost incurred (MC) & $\mathbf{4 9 . 8 5}$ & $\mathbf{4 1 . 5 4}$ \\
\hline Profit margin (MM) & $\mathbf{7 0 . 1 5}$ & $\mathbf{5 8 . 4 6}$ \\
\hline Selling price to consumer & 120.00 & 100.00 \\
\hline
\end{tabular}

Source: Author's own computation based on field data 2018 
Table.3 Calculation of marketing efficiency for marketing channel II

\begin{tabular}{|c|c|c|}
\hline Particulars & Value & Percent \\
\hline Selling price of camel milk @ `60/litre (MP) & $\mathbf{6 0}$ & $\mathbf{5 0 . 0 0}$ \\
\hline Purchase price of collection centre & 60 & 50.00 \\
\hline Bottles/ bottling charges & 6 & 5.00 \\
\hline Transportation cost & 5 & 4.17 \\
\hline Labeling & 2.5 & 2.08 \\
\hline Freezing & 3 & 2.50 \\
\hline Filling Charges & 1.5 & 1.25 \\
\hline Processing & 1.75 & 1.46 \\
\hline Total cost incurred (MC) & $\mathbf{7 9 . 7 5}$ & $\mathbf{6 6 . 4 6}$ \\
\hline Profit margin (MM) & $\mathbf{4 0 . 2 5}$ & $\mathbf{3 3 . 5 4}$ \\
\hline Selling price to consumer & 120 & 100.00 \\
\hline
\end{tabular}

Source: Author's own computation based on field data 2018

Table.4 Calculation of marketing efficiency for marketing channel III

\begin{tabular}{|c|c|c|}
\hline Particulars & Value & Percent \\
\hline Selling price of camel milk @ 50/ litre (MP) & $\mathbf{5 0}$ & $\mathbf{4 1 . 6 7}$ \\
\hline Purchase price of collection centre & 50 & 41.67 \\
\hline Bottles/ bottling charges & 6 & 5 \\
\hline Transportation cost & 5 & 4.17 \\
\hline Labelling & 2.5 & 2.1 \\
\hline Freezing & 3 & 2.5 \\
\hline Filling Charges & 1.5 & 1.25 \\
\hline Processing & 1.75 & 1.46 \\
\hline Total cost incurred (MC) & $\mathbf{6 9 . 7 5}$ & $\mathbf{5 8 . 1 5}$ \\
\hline Profit margin (MM) & $\mathbf{5 0 . 2 5}$ & $\mathbf{4 1 . 8 5}$ \\
\hline Selling price to consumer & 120 & 100.00 \\
\hline
\end{tabular}

Source: Author's own computation based on field data 2018

Table.5 Calculation of marketing efficiency for marketing channel IV

\begin{tabular}{|c|c|c|}
\hline Particulars & Value & Percent \\
\hline Cost of Production of camel milk & $\mathbf{2 0}$ & \\
\hline Transportation cost to consumer & 5 & 4.17 \\
\hline Handling Cost & 5 & 4.17 \\
\hline Total Cost Incurred (MC) & $\mathbf{1 0}$ & $\mathbf{8 . 3 4}$ \\
\hline Profit margin (MM) $^{\mathbf{2}}$ & $\mathbf{9 0}$ & $\mathbf{9 1 . 6 6}$ \\
\hline Selling price to consumer (MP) & $\mathbf{1 2 0}$ & $\mathbf{1 0 0 . 0 0}$ \\
\hline
\end{tabular}

Source: Author's own computation based on field data 2018 
Table.6 Calculation of marketing efficiency (// 1 litres)

\begin{tabular}{|c|c|c|c|c|}
\hline Particulars & $\begin{array}{c}\text { Marketing } \\
\text { Channel } \\
\text { I }\end{array}$ & $\begin{array}{c}\text { Marketing } \\
\text { Channel } \\
\text { II }\end{array}$ & $\begin{array}{c}\text { Marketing } \\
\text { Channel } \\
\text { III }\end{array}$ & $\begin{array}{c}\text { Marketing } \\
\text { Channel } \\
\text { IV }\end{array}$ \\
\hline $\begin{array}{c}\text { Selling price of camel } \\
\text { rearers }\end{array}$ & 35 & 60 & 50 & 120 \\
\hline Transportation cost & 2 & 5 & 5 & 5 \\
\hline Bottles/ bottling charges & 4.35 & 6 & 6 & \\
\hline Ice & 7.5 & - & - & - \\
\hline Labeling & - & 2.5 & 2.5 & - \\
\hline Freezing & - & 3 & 3 & - \\
\hline Filling Charges & - & 1.50 & 1.50 & - \\
\hline Processing & - & 1.75 & 1.75 & - \\
\hline Miscellaneous expenses & 1 & - & - & 5 \\
\hline Profit margin & 70.15 & 40.25 & 50.25 & 91.66 \\
\hline Selling price to consumer & 120 & 120 & 120 & 120 \\
\hline
\end{tabular}

Source: Author's own computation based on field data 2018

Table.7 Comparison of marketing efficiency for marketing channels

\begin{tabular}{|c|c|c|c|c|}
\hline Channel & MP & MC & MM & $\mathbf{M}_{\mathbf{e}}$ \\
\hline Channel I & 35 & 49.85 & 70.15 & 0.29 \\
\hline Channel II & 60 & 79.75 & 40.25 & 0.50 \\
\hline Channel III & 50 & 69.75 & 50.25 & 0.42 \\
\hline Channel IV & 120 & 10 & 0 & 12.00 \\
\hline
\end{tabular}

Source: Author's own computation based on field data 2018

Price spread in marketing channel III

Camel rearers $\rightarrow$ Collection Centre (Rearers bear the cost of collection) $\rightarrow$ Consumer

In Marketing Channel III, the camel rearer sells milk to organized private player typically a company and the company through its distribution network sells the camel milk to consumer through retail stores, milk parlor or doorstep delivery.

The price received by camel rearer is ' 50 /litre as per the case study of a company operating in Bikaner. Company can distribute camel milk in pasteurized form or in powder form. As this research work is dedicated to camel milk, the price spread is explained in following table 4 only for pasteurized camel milk form as a product:

Marketing Efficiency for Marketing Channel III is as follows:

$\mathrm{ME}=\mathrm{MP} /(\mathrm{MC}+\mathrm{MM})=50 /(69.75+50.25)$

$=0.42$

The marketing efficiency (ME) for Marketing Channel III is 0.42 .

\section{Price spread in marketing channel IV}

Camel rearers $\rightarrow$ Consumer 
In Marketing Channel IV, the camel rearer does not depend on any type of intermediary and he directly sells to the consumer with his own transport facilities.

Price spread in Marketing Channel IV (Camel rearers $\rightarrow$ Consumer)

Marketing Efficiency for Marketing Channel IV is as follows:

$\mathrm{ME}=\mathrm{MP} /(\mathrm{MC}+\mathrm{MM})=120 /(10+0)=12$

Here, marketing margin is considered zero because camel rearer is not sharing marketing margin with anybody but himself. In marketing channel IV, there is no intermediary. ${ }^{1}$ Cost of production is mentioned especially in marketing channel IV just to understand how cost is spread when camel rearer himself market camel milk. The marketing efficiency (ME) for Marketing Channel IV is $12 .{ }^{2}$ For marketing channel IV, there is no intermediary hence marketing margin is not a cost item but earning to the camel rearers. Hence, Marketing Margin (MM) is assumed to be zero for calculating the marketing efficiency for the marketing channel IV (Table 5-7).

The most efficient marketing channel is:

Marketing Channel IV: Camel rearers $\rightarrow$ Consumer

In this channel, there were no intermediaries hence very little amount of marketing cost and marketing margin incurred in this channel. The marketing efficiency based on Acharya's modified formula for marketing channel IV was $\mathrm{M}_{\mathrm{e}}$ of 12 .

If camel rearer cannot handle marketing activity himself than marketing channel II is better than marketing channel I and marketing channel III. Marketing efficiency of marketing channel II is 0.50 . The marketing channel II is a better choice as it is a cooperative model which is more social empowering than company based model.

The study revealed that majority of camel rearers were illiterate ( 40.5 per cent) followed by "can read and write" category (35.5 per cent), "can read only" category (15.5 per cent), "primary" category (3.5 per cent), "high school" category (2.5 per cent), "middle education" category (1.5 per cent) and "graduate" category (1 per cent). The current generation is going for higher education while the past generation was illiterate and belongs to the "can read and write" category only. The majority of camel rearers were using camel milk for domestic consumption. 26.5 percent of the sample was using camel milk for sale and 28.5 percent of the samples were using camel milk for both purposes. The National Research Centre on Camel (NRCC), Bikaner had played an important role in the growth of camel milk 65.5 percent camel rearers had been benefited in terms of training, extension and 34.5 percent did not visit the NRCC campus for any sort of training and workshops.

The marketing channel in which camel rearer directly supplies to the consumer on his own is found most efficient as per Acharya's Modified Formula for marketing efficiency for a marketing channel. Due to lack of scalability and professionalism in this marketing channel, marketing channel II which involves intermediary, a cooperative, between camel rearer and consumer is found suitable as per marketing efficiency. The other two marketing channels were a) rearer to trader and trader to consumer and b) rearer to company and company to the consumer.

\section{References}

Agrawal, R P., Singh, G, Nayak, K C., Kochar, D K., Sharma, R C., Beniwal, 
R., and Gupta, R. 2004. Prevalence of diabetes in camel milk consuming 'RAICA' Rural Community of northwest Rajasthan. International Journal of Diabetes in Developing Countries. 24: 109-14.

Agrawal, R P., Beniwal, R., Sharma, S., Kochar, D. K., Tuteja, F. C., Ghorui, S. K., and Sahani, M. S. 2005. Effect of raw camel milk in type 1 diabetic patients: A 1-year randomized study. Journal of Camel Practice and Research. 12(1): 27.

Agrawal, R. P., Beniwal, R., Kochar, D. K., Tuteja, F. C., Ghorui, S. K., Sahani, M. S., and Sharma, S. 2005. Camel milk as an adjunct to insulin therapy improves long-term glycemic control and reduction in doses of insulin in patients with type-1 diabetes: A 1-year randomized controlled trial. Diabetes research and clinical practice. 68(2): $176-177$

BAHS (2012). Basic Animal Husbandry Statistics, retrieved from http//www.dahd.nic.in on 1 February 2017.

FAOSTAT, (2015). Animal Production Yearbook, Food \& Agricultural Organization, Rome, Italy.
https:faostat3.fao.org/download/Q/QA/ E (Accessed 8 February 2017)

Khanna, N. D. 1986. Camel as a milch animal. Indian Farming. 36(5), 39-40.

Livestock Census Report (2012).19th Livestock Census-2012 retrieved from http://dahd.nic.in/sites/default/files/Liv estock\%20\%205.pdf on 2 February 2017.

Meena, S., Rajput, Y. S., and Sharma, R. (2014). Comparative fat digestibility of goat, camel, cow and buffalo milk. International Dairy Journal. 35(2): 153-156.

Raghvendar S, Shukla S, Sahani M S (2004). Prospects for adding value to camel milk in India. In: International conference on serving the camel and peoples' livelihoods: proceedings of an international conference held on 23-25 November 2004 in Sadri. Lokhit Pashu-Palak Sansthan, Sadri, Rajasthan, India, p38 www.pastoralpeoples.org/docs/camel_ conf_proc.pdf

Singh, R., Mal, G., Kumar, D., Patil, N. V., and Pathak, K. M. L. 2017. Camel milk: an important natural adjuvant. Agricultural Research. 6(4): $327-340$.

\section{How to cite this article:}

Gurbir Singh, Amita Sharma and Raghvendar Singh. 2019. Marketing Efficiency of Camel Milk under Different Supply Chains in Rajasthan State of India. Int.J.Curr.Microbiol.App.Sci. 8(12): 1036-1046. doi: https://doi.org/10.20546/ijcmas.2019.812.132 